\title{
HEIDEGGER E A TRANSCENDÊNCIA DO BEM
}

Heidegger and the transcendence of the good

Jean-François Lavigne

Resumo: Proponho analisar a interpretação heideggeriana de Platão, seguindo o conselho hermenêutico dado pelo próprio Heidegger para ler a ontologia platônica: segundo o pensador alemão, a doutrina platônica da verdade contém um silêncio bastante estranho, o silêncio sobre o estatuto ontológico da Ideia do Bem e sua relação ao conjunto do inteligível. Por meio de uma leitura detalhada de textos de Platão e Heidegger, procurarei averiguar a pertinência da identifição heideggeriana de tal silêncio e pôr em questão a fenomenalização ou não fenomenalização do Bem ou Bom platônico.

Palavras-chave: Ser, Bem, Verdade, Inteligível, Fenômeno.

Abstract: This study aims to analyse the Heideggerian interpretation of Plato, following the hermeneutical advice, given by Heidegger himself, on how to understand the Platonic ontology. According to the German thinker, Plato's doctrine of truth contains a rather strange silence, one that concerns the ontological status of the Idea of Good and its relationship with the whole intelligible. Through a detailed reading of Plato and Heidegger's texts, I will attempt to prove the appropriateness of the Heideggerian identification of such silence and question the phenomenisation or non-phenomenisation of the Platonic Good.

Key-words: Good, Truth, Intelligible, Phenomenon.

\footnotetext{
" Professor da Université de Montpellier III - Paul Valéry, France. Artigo inédito traduzido por Juvenal Savian Filho (Departamento de Filosofia da Unifesp). As citações indicam suas fontes e respectivos tradutores. Quando não houver indicação de tradutores, a tradução terá sido feita pelo autor do artigo, J.-F. Lavigne. Todas as traduções de citações em português são feitas pelo tradutor do artigo, J. Savian Filho. Artigo recebido em 30/08/2018 e aprovado para publicação em 10/09/2018.
} 


\section{O silêncio hermenêutico heideggeriano quanto à transcendência do Bem}

$\mathrm{N}$ o seu curso de inverno de 1924-1925, consagrado ao Sofista de Platão, Heidegger faz a seguinte observação, em benefício de uma breve digressão sobre o estatuto central geralmente atribuído à doutrina das Ideias na filosofia de Platão:

Para quem aprendeu a compreender um autor, talvez não seja possível considerar uma posição fundamental de sua interpretação aquilo que o autor mesmo declara ser o mais importante. Aquilo sobre o que o autor silencia é o mesmo pelo qual se deve começar para compreender o que o autor designa como o que lhe é próprio. ${ }^{1}$

Proponho seguir a via interpretativa que Heidegger indica, aplicando seu conselho hermenêutico à sua leitura da ontologia platônica. Com efeito, na interpretação heideggeriana da doutrina platônica da verdade, há um silêncio bastante estranho. Silêncio tanto mais perturbador por versar sobre um elemento dessa doutrina que, da perspectiva da coerência do logos platônico, é absolutamente fundamental, pois trata-se nada menos do que do estatuto ontológico da Ideia do Bem e de sua relação ao conjunto do inteligível. Se, então, desejamos, segundo a fórmula de Heidegger, "compreender o que [ele] designa como o que lhe é próprio" em sua interpretação do platonismo, é examinando "aquilo sobre o que [ele] silencia" que chegaremos o mais seguramente possível a identificá-lo e a descobrir o seu sentido último.

O que Heidegger designa como "o próprio" de sua meditação sobre a doutrina platônica da Ideia? Encontra-se uma primeira formulação, ainda bastante indireta, no mesmo curso de Marburgo sobre o Sofista:

(...) nós não compreendemos (...) o sentido primeiro da teoria das Ideias, tanto quanto a opacidade que a acompanha, a não ser que nos fixemos no ponto em que aparece em primeiro lugar muito naturalmente o eidos, quer dizer, no aletheuein no qual o eidos sobressai explicitamente. É dessa perspectiva que se deve compreender por que Platão diz que a Ideia é o ser propriamente dito.

Heidegger acrescenta:

Já vimos: o eidos é a arche da conexão de conjunto de noesis e de poiesis na techne. (...) A techne é o solo sobre o qual algo como o eidos torna-se, em primeiro lugar, visível. ${ }^{2}$

\footnotetext{
${ }^{1}$ HEIDEGGER, M. Platon - Le Sophiste. Trad. fr. Jean-François Courtine e Pascal David. Paris: Gallimard, 2001, p. 52.

${ }^{2}$ Ibidem, p. 52.
} 
Nesse primeiro período de sua releitura de Platão, Heidegger considera então que, para compreender o estatuto ontológico da Ideia platônica, o eidos, é preciso encará-lo no quadro daquilo que ele tem por seu tipo originário de manifestação, o quadro desse modo particular de desvelamento - aletheuein - que é a techne. É sobre o "solo" da techne que o eidos tornar-se-ia "em primeiro lugar visível", pela razão segundo a qual, no processo técnico (cujo modelo que fornece o paradigma aqui é a arquitetura, retomada da Ética nicomaqueia) "o eidos é a arche da conexão entre noesis e poiesis".

Essa tese comporta duas afirmações claras, que destacaremos antes de mais nada: (1) a Ideia ou eidos é arche do ponto de vista da articulação noesis/poiesis; (2) para Platão, tal como lido por Heidegger, “a Ideia é o ser propriamente dito".

As duas afirmações encontram-se no pano de fundo da tese defendida por Heidegger em seu ensaio de 1940, A doutrina platônica da verdade, cujo texto foi publicado mais tarde, em 1942 e 1947. A tese proposta no ensaio de 1940 é diferente e mais radical; porém, ela consiste em sublinhar, ainda uma vez, a prioridade conferida a eidos/idea como objeto de um ver intelectual na determinação platônica da verdade. A tese diretiva do ensaio sustenta que, com Platão e a Alegoria da Caverna, "a aletheia fica sob o jugo da Ideia", ${ }^{3}$ de modo que, doravante, é a "a essência da Ideia" 4 que rege a possibilidade do des-velamento do ente; ora, a própria visão intelectual da idea é ligada à exigência da "correção do olhar" (no texto de Platão, orthotes), e de tal maneira que, na concepção platônica da verdade, é a conformação adequada - o orthotes - do olhar (idein) com o inteligível que é o objeto-correlato (portanto, a idea) que decidiria sobre o acesso aos "entes verdadeiros" (ta ontos onta). Platão introduziria, assim, uma "preeminência conferida à ideia e ao idein sobre a aletheia", preeminência esta que opera uma verdadeira "mutação na essência da verdade". ${ }^{5} \mathrm{Tal}$ mutação consistiria nisto: não é mais o des-velamento efetuado pela luz da aletheia que abriria, por si mesmo e por seu próprio desdobramento, o acesso ao ente; antes, seria a submissão do olhar aos caracteres da Ideia, do objeto inteligível, que decidiria sobre a efetivação do des-velamento mesmo. O texto platônico que Heidegger cita aqui é aquele do livro VII de República 515d1-4, onde se lê:

Que pensas que ele diria [aquele que teria sido forçado a levantar-se de seu lugar e a virar-se para os objetos cujas sombras são projetadas sobre a parede da caverna e depois para a luz de fora] se alguém lhe dissesse que antes ele não via senão coisas sem importância (phluarias), mas que agora, estando um pouco mais perto do ente (tou ontos) e tendo sido virado (te-

\footnotetext{
${ }^{3}$ HEIDEGGER, Questions II. Trad. fr. Kostas Axelos et alii. Paris: Gallimard, 1990, p. 152

${ }^{4}$ Ibidem, p. 152-153.

${ }^{5}$ Idem, ibidem.
} 
trammenos) para coisas que são muito mais (pro mallon onta), ele vê mais corretamente (orthoteron blepoi)?

Ver "mais corretamente", quer dizer, ver com maior orthotes ou correção do olhar, é, portanto, essencialmente olhar para objetos que "são muito mais", pois esses objeto seriam as Ideias. Heidegger comenta como segue as duas palavras decisivas orthoteron blepoi:

Passar de um ente a outro é olhar de um modo mais exato. Tudo é subordinado ao orthotés, à exatidão do olhar. Por essa exatidão, a visão e o conhecimento tornam-se corretos, de sorte que finalmente elas mirem diretamente a Ideia suprema e se fixem nessa "visada". (...) Essa adaptação da percepção ou do idein à idea acarreta uma homoiosis, um acordo do conhecimento e da coisa mesma. ${ }^{6}$

Essa leitura fundamenta, então, a subordinação da aletheia à Ideia e à sua visão exata (o orthotes) sobre o fato de que a idea/eidos é o ente verdadeiro, o ontos on que o conhecimento procura. Encontra-se, assim, orquestrada diferentemente, e ao mesmo tempo radicalizada, a dupla afirmação do curso de 1924-1925 sobre o Sofista:

- "a Ideia ou eidos é arche"; e, por outro lado,

- "a Ideia é o ser propriamente dito".

Essa afirmação dupla e a identificação da idea ao que é o ente segundo Platão contêm, no entanto, uma dificuldade por causa do estatuto particular da Ideia suprema, a Ideia do Bem. Com efeito, no ensaio de 1931/1940/1942/1947, Heidegger não a encara senão da perspectiva do ver e do aparecer, da operação do tornar visível que corresponde à relação de analogia entre o Bem e o Sol, a ponto de ele interpretar a causalidade atribuída por Platão à Ideia do Bem em termos de fazer-aparecer e de fenomenalização. Ele diz em particular:

Uma vez percebida a Ideia suprema, então (...) percebe-se (como decorrendo da Ideia suprema) que, para todos os humanos, ela [a Ideia do Bem] é manifestamente a (...) causa de tudo o que é bom (em seu comportamento), assim como de tudo o que é belo, ${ }^{7}$ (...) quer dizer, do que se mostra nesse mesmo comportamento, de tal maneira que faz aparecer sua própria e-vidência nisso que ela tem de brilhante. (...) "O Bem" confere a aparição da evidência, a aparição disso em que a coisa presente possui a consistência de seu ser. ${ }^{8}$

Em suma, a Ideia do Bem, segundo Heidegger, compartilha o estatuto e a função de toda outra idea; ela é arche por ser, ao mesmo tempo, objeto e condição da visão, e sua causalidade exerce-se segundo a ordem do aparecer e da manifestação. Ora, dessa maneira, Heidegger deixa em silêncio

\footnotetext{
${ }^{6}$ Idem, ibidem. O itálico é nosso.

${ }^{7}$ É assim que, nesta passagem, Heidegger traduz República 517c1-2.

${ }^{8}$ HEIDEGGER, Questions II, op. cit, p. 151. Itálicos nossos.
} 
o dado fundamental de que, para Platão, o Bem - assim como o Sol na ordem do visível - possui um duplo estatuto e exerce uma dupla função: segundo a ordem do ver intelectual - do conhecimento -, ele também é efetivamente caracterizado como uma idea, objeto de uma visão possível, e, sob esse aspecto, ele compartilha as características gerais de toda Ideia; mas, em revanche, segundo a ordem do ser - do ponto de vista da ousia -, Platão afirma que o Bem transcende todo o domínio do ente, pois, segundo os termos do final do livro VI da República, ele permanece epekeina tes ousias, "para além da essência" (cf. República VI, 509b9).

Essa transcendência do Bem segundo a ordem do ser, da qual Heidegger, em seu ensaio de 1940/42/47, ${ }^{9}$ não diz uma palavra sequer, obriga a pôr em questão sua tese de que "a Ideia é o ser propriamente dito", pois não somente Platão distingue expressamente entre idea e ousia conforme dois gêneros de relações formalmente diferentes, mas sobretudo Platão admite que uma mesma coisa, o Bem, pode, ao mesmo tempo, ser uma Ideia (prestar-se, portanto, a uma visão intelectual) e todavia não se deixar integrar no domínio do ente ou do ser, pois essa "Ideia" particular é "para além da ousia". A transcendência do Bem platônico em relação à essência torna contestável também a afirmação heideggeriana segundo a qual "a Ideia, ou o eidos, é arche", pois, se o Bem, em si mesmo, é "para além da ousia" e exerce, a partir dessa posição de transcendência mesma, sua causalidade ontológica sobre as essências (ousiai), bem como, por meio destas, sobre as coisas sensíveis, então é ele que é arche. Além disso, a maneira como ele exerce essa causalidade de Princípio (arche) no tocante ao ente (essências, ousiai, e entes de todo nível, onta) não pode ser a mesma que exerce uma idea que é igualmente uma ousia e que não se situa epekeina, "para além". Com efeito, em relação ao sensível a Ideia é causa por méthexis, por participação, ao passo que, por ser "para além da essência", é necessariamente outra a maneira como o Bem é causa.

Seria, porém, incorreto dar a entender que o silêncio de Heidegger sobre esse ponto consistiu pura e simplesmente em uma omissão de mencionar e interpretar a célebre e enigmática fórmula de República VI, 509b9, epekeina

\footnotetext{
${ }^{9}$ Convém precisar de saída que esse silêncio é total apenas no ensaio intitulado $A$ doutrina platônica da verdade, em suas diferentes versões sucessivas (1940/42/47). Já no curso de inversno de 1931/32, intitulado Da essência da verdade (Vom Wesen der Wahrheit, G. A., tomo 34; trad. francesa de Alain Boutot, Paris, Gallimard, 2001), cuja redação foi a fonte do ensaio ulterior, e onde ele havia procedido a uma análise aprofundada da Alegoria da Caverna e do Teeteto, Heidegger não somente menciona essa relação particular pela qual Platão situa o Bem "para além da essência", citando a passagem-chave em grego e desenvolvendo um comentário sobre ela, mas também consagra uma longa seção de seu texto à interpretação da maneira como o Bem é causa e desse epekeina ou dessa situação supereminente de "para além" da essência que Platão atribui-lhe de maneira assaz enigmática. Não pretendemos, portanto, dizer aqui que, de maneira global e constante, Heidegger omitiria pura e simplesmente o exame ou mesmo a evocação desse aspecto decisivo da relação do Bem com as Ideias. Seu silêncio é, a um só tempo, mais circunscrito e mais sutil: o ponto preciso sobre o qual ele incide é explicado aqui na sequência (ver o próximo parágrafo).
} 
tes ousias, "para além da essência". Ao contrário, Heidegger reserva, em seu curso de inverno de 1931/32, uma passagem importante do capítulo II da primeira parte (\$§ 12-15), onde, depois de ter citado por extenso e traduzido o texto grego, ele escreve:

Analogicamente se deve dizer que, assim como, no domínio do sensível, é próprio do ente não apenas ser-visto, mas também ser, assim também aqui é próprio do noumenon não somente a aletheia, mas, a um só golpe, a ousia. Na verdade, assim como antes o Sol não podia ser um devir, mas possibilitava o devir, assim também agora o agathon não pode ser um ser nem desvelado, mas é para além (epekeina), para além do ser como também para além do desvelado"*.10

De um ponto de vista factual, então, Heideger não deixa em silêncio nem a fórmula pela qual Platão afirma a transcendência do Bem em relação ao ser e à ousia, nem - o que é mais importante - a distinção literalmente presente no texto entre as duas relações que o Sol e o Bem mantêm, respectivamente, com os entes de seus domínios: tornar cognoscível, de uma parte; dar ser e ser algo, de outra parte. No entanto, se ainda é possível falar de um silêncio no comentário heideggeriano, tal se faz no sentido de um silêncio hermenêutico, na medida em que a interpretação elaborada por Heidegger termina por fazer calar a intenção mais própria e mais viva do texto platônico, desviando-lhe sua significação manifesta em dois pois pontos absolutamente essenciais:

(1) embora leve em consideração a distinção entre a relação ontológica e a relação gnoseológica, Heidegger omite-se constantemente de considerar o fato de que não é como Ideia que o Bem é declarado epekeina por Platão. Heidegger insiste em explicar a transcendência do Bem no horizonte da problemática da verdade como aletheia, enquanto Platão precisa expressamente que a "luz" da aletheia não concerne ao ente senão como conhecido ou cognoscível (gignoskomenois), ${ }^{11}$ quer dizer, no seio de uma relação com o Bem que não é precisamente aquela na qual se estabelece a transcendência dele; afinal, o Bem é dito transcendente em relação à essência segundo a ordem do ser, e não a do conhecer. Assim, a dissociação platônica entre o Bem como ontologicamente transcendente e a problemática do conhecimento desaparece no comentário que dela faz Heidegger. Ora, o Bem como Ideia, ou aquela "Ideia do Bem" cujo sentido Platão buscava determinar, justamente não é o que se diz ser "para além"!;

\footnotetext{
* Desvelado traduz, aqui, a expressão francesa ouvert sans retrait (aberto que não se retira/ oculta), que, por sua vez, foi a opção de Alain Boutot (na tradução citada por J.-F. Lavigne) para traduzir Unverborgenheit (condição do que não é velado; desvelamento; desocultamento). N. do T.

${ }^{10}$ HEIDEGGER, De l'essence de la vérité, op. cit., p. 129.

${ }^{11}$ Cf. PLATÃO, República VI, 509b6-9.
} 
(2) mais profundo e mais carregado de consequências é o desvio que Heidegger impõe ao sentido da causalidade própria do Bem. Tão logo resumiu - segundo o que procuramos mostrar acima - a distinção platonica das duas relações do Bem com o ente, Heidegger impõe imediatamente sua interpretação da causalidade do bem como possibilidade, ou, mais precisamente, como tornar-possível ou potencialização. Com efeito, ele escreve na sequência do último trecho citado aqui:

Torna-se claro, assim, que o Bem é certamente uma dunamis e possui, então, o que caracteriza as Ideias (o caráter da possibilização e da potencialização), e ele o possui mesmo no mais alto grau; o ser e o desvelado, em geral, ficam hup'ekeinou, sob a potência que lhes dá o poder. Mas, nessa potencialização, o Bem ultrapassa e domina ambos: de uma parte, que o ente seja visto, ou seja, conhecido, e, de outra parte, que ele seja acima de tudo um ente. Esse modo de ultrapassamento, tal como enunciado a respeito da Ideia mais elevada, não consiste simplesmente em ser indiferentemente mais elevado e acima daquilo que ele domina (...). Ao contrário, ele ultrapassa no sentido das Ideias, ou seja, no sentido do ser-Ideia. Mas, na medida em que ser-Ideia quer dizer dar poder para ser, tornar manifesto o ente, então nessa mesma medida, para a Ideia do Bem, ultrapassar quer dizer, por sua vez, que essa Ideia ultrapassa o ser como tal e, em geral, a verdade. ${ }^{12}$

Essa interpretação imediata do Bem como dunamis é diretamente contrária ao enunciado literal do texto platônico, pois o que Platão define como potência ou possibilidade (dunamis) na estrutura da visão sensível e analogicamente na noésis do inteligível não é o princípio nem a operação do princípio (do Sol, dispensador da luz, ou do Bem, fonte da aletheia), mas, bem ao contrário, a disposição virtual que devem apresentar igualmente o sujeito capaz de visão (o olho ou alma) e o objeto em si suscetível de ser visto (intelectualmente intuicionado), quer dizer, de um lado, a aptidão para ver (aptidão para compreender, a inteligência), e, de outro lado, a cor (ou seu análogon inteligível) como aptidão para ser visto. $O$ texto do final do livro VI é límpido sobre este ponto: Platão considera que a visibilidade do visível, no sentido de sua manifestação visual, supõe que o objeto possua, de antemão, certo caráter que o torna apto à refletir a luz e a entrar, assim, em manifestação. É essa condição de possibilidade primeira, anterior à aclaração pela luz, e portanto, não visível em si mesma, que Platão chama "a cor". Em revanche - e por conseguinte -, a operação própria do Sol é a de atualizar essa simples possibilidade: é por isso que o Sol não tem função tornar possível a visão (o que significaria que ele transmite aos objetos sua cor invisível, a qual é sua visibilidade potencial), mas sim de torná-la efetiva, de efetuar $\mathrm{em}^{\text {at } \mathrm{o}^{13}}$ a manifestação visual das cores e de seus contrastes (por onde se opera efetivamente o ver) e também, na mesma operação, de fazer passar à ação a capacidade perceptiva do olho

${ }^{12}$ HEIDEGGER, De l'essence de la vérité, op. cit., p. 130.

${ }^{13}$ Podemos servir-nos aqui da terminologia aristotélica, sem risco de distorsão doutrinal. 
(que é a outra condição, subjetiva, desse ver). Afinal, o que chamamos, por equivocidade, de "o visível" não é, na realidade, senão algo "visto", como "já visto", e, justamente como visto e "tal como visto", acessível a um re-ver. Heidegger parece jogar bastante confusamente com essa equivocidade para atribuir ao princípio platônico do conhecer (sensível ou intelectual) uma "potencialização" que é incompatível com seu verdadeiro conceito: o Sol é, para Platão, fonte ativa e atual da luz, fazendo passar a ato a cor potencialmente visível; assim também, por consequência, o Bem deve ser concebido como o princípio que provoca efetivamente a iluminação intelectual: a referência ao Bem é o que torna a alma inteligente em ato, não no sentido de que ela lhe conferiria sua dunamis (dar-lhe-ia a inteligência como capacidade, aptidão ao noein), mas, bem ao contrário, no sentido de que ela aciona atualmente em si a captação da evidência; e, simetricamente, a relação ao Bem deve ser concebida como o que torna evidente um conteúdo, um objeto ou uma relação, os quais, em si e já por si mesmos, são uma estrutura inteligível prévia à captação evidente.

A falsificação ou a confusão cometida por Heidegger desdobra-se e agrava-se quando aquilo que ele pretende determinar em sua essência pelo conceito de potencialização corresponde ao Bem, visualizado em seu ultrapassamento - ao modo do epekeina - tanto do domínio do cognoscível (o desvelado) como do domínio da ousia (o ser): não somente, como já vimos, a relação designada por Platão pelo epekeina tes ousias não concerne, em absoluto, ao domínio da manifestação ou do conhecimento, mas, sobretudo, o Bem, como algo que ultrapassa a essência, pode ainda menos deixar-se determinar como possibilização ou potencialização, porque sua função é ontológica (e não fenomenológica ou gnoseológica), e consiste diretamente em causar, isto é, em fazer ser, seja no modo do engendramento natural (genesis), seja no modo do que significam - em um sentido que deveremos precisar adiante - o verbo grego einai e seus derivados on e ousia. Assim, o Sol e o Bem só podem ser princípios ativos, atualizantes. É, portanto, duplamente inexato pretender que o Bem "ultrapassa no sentido das Ideias, ou seja, no sentido do ser-Ideia" e que a transcendência ontológica do Bem é um "ultrapassamento que potencializa".

Na medida em que essa dupla alteração termina por ocultar o que constitui o coração da tese metafísica do platonismo da República, a saber, a autonomia ontológica do Bem como princípio final absoluto de apreciação ética e de organização política em relação ao conhecimento subjetivo e a seu ponto de vista relativizante, pode-se dizer que o sentido fundamental da transcendência platônica do Bem é efetivamente silenciado pelo processo de interpretação-redução a que é submetido por Heidegger.

O estatuto particular da Ideia do Bem em relação ao ser obriga, então, a romper a enganosa uniformidade do domínio da Ideia/eidos que Heidegger tenta sustentar. A dupla relação segundo a qual o Bem é visualizado por Platão obriga sobretudo a não o reduzir ao único estatuto de idea teleutaía, 
Ideia Suprema, e, portanto, a não mais situá-lo em uma continuidade simples e homogênea com o conjunto das outras Ideias.

Como é sabido, a esse silêncio de Heidegger sobre o caráter metaontológico do Bem platônico corresponde, em Emmanuel Lévinas, a ênfase inversa, aquela da ética como relação primeira "para além da essência". A segunda grande obra de Lévinas, Outramente que ser, subintitulada "ou para além da essência", retoma literalmente o epekeina tes ousias de Platão. Afinal, é nessa "brecha do epekeina"14 que Lévinas vê a ruptura da totalidade que dá origem, em Heidegger, à exclusiva dominação da ontologia, enquanto é também nela que Lévinas situa a abertura para uma alteridade, para essa dimensão de altura e de transcendência que impede ao espírito humano, tocado pelo desejo do absoluto, ficar preso na circularidade fechada da interconexão das Ideias, onde se refaz sem cessar o ciclo eterno do Mesmo.

Em torno do enigma do sentido preciso da transcendência do Bem platônico, desse excesso do Bem sobre as essências e sua onto-lógica, concentra-se então, também, o conflito de duas grandes leituras de Platão ou de duas compreensões do platonismo elaboradas no século XX e radicalmente incompatíveis. O problema que iremos examinar tem, portanto, também esta significação segunda: qual relação Platão estabelece entre ética e conhecimento e entre ética e ontologia, para que o Bem possa, de um modo que é necessário determinar, transcender as essências? Qual é a natureza dessa transcendência? Que gênero de alteridade implica essa "passagem para além" da ousia?

\section{O texto da República}

Para tentar resolver esse enigma, o próprio Platão indica o método: deixemo-nos guiar pela analogia, construída com todo o rigor, entre a estrutura da visão sensível e a estrutura da intuição do inteligível, entre o domínio em que o Sol é o soberano (kúrios) e aquele sobre o qual reina o sol da inteligência, o Bem.

No fim do livro VI da República, linhas 507d11-e5, Sócrates mostra que a vista dos objetos sensíveis supõe quatro condições:

(1) um órgão dotado da aptidão para ver (um olho saudável, potencialmente vidente), aptidão esta que é nomeada opsis por Platão (507d11);

(2) o exercício voluntário, por parte daquele que vê, dessa faculdade de ver (epicheirountos tou échontos chrésthai aute - 507d12);

\footnotetext{
${ }^{14}$ Expressão precisa de Jean-François Mattéi no estudo por ele consagrado a esse aspecto essencial do pensamento de Lévinas. Cf. LÉVINAS, E. Positivité et transcendance. Paris: PUF, 2000, p. 73-87.
} 
(3) objetos coloridos, quer dizer, possuidores em si mesmos de um caráter que os torna suscetíveis de aparecer; trata-se dessa visibilidade potencial (orásthai dunamis, literalmente "capacidade de ser visto" - 507d12) que é justamente a cor (chróa);

(4) enfim, a luz (phós - 507e4), que a um só tempo faz resplandecer as cores e ilumina o olho, atualizando assim, por uma só operação, as duas potencialidades (dunamis) simétricas previamente reconhecidas.

O texto diz, com efeito:

- Admitindo que os olhos são dotados da faculdade de ver (opsis); e que aquele que possui essa faculdade esforça-se por dela se servir; e que os objetos aos quais ele a aplica são coloridos; se não intervier um terceiro elemento (génos tríton), destinado propriamente, por natureza, a esse fim precisamente (idia ep'autó touto pephukós), tu sabes que a vista não perceberá nada e que as cores serão invisíveis

- De qual elemento falas?

- Disso que tu chamas de luz. ${ }^{15}$

Dessa estrutura se extraem quatro notáveis relações.

Primeira relação: as coisas visíveis são, no tocante à sua visibilidade, dependentes do Sol como fonte (e princípio, arche) da luz. O Sol é, então, o soberano do visível, na medida em que não precisa ser iluminado para aparecer; ele é sem cor e não precisa refletir a luz para aparecer, como é o caso dos corpos visíveis. Mas, ao mesmo tempo, ele não se exclui do domínio do visível; ao contrário, ele é, por seu esplendor superior, mais luminoso e ainda mais intensamente visível do que qualquer outro objeto. Ele é, portanto, ao mesmo tempo, o mais difícil a ver pelo olho, porque ele ofusca, e supremamente integrado ao visível, pois se autoilumina e pode, a justo título, ser também objeto da visão. Sócrates diz, a esse respeito, que o Sol não é a vista, mas, sendo causa dela (aitiós - 508b9-10), é visto por ela. $\mathrm{O}$ efeito recebe de sua causa a possibilidade de retornar a ela. É assim que, na Alegoria da Caverna, imediatamente depois do final do livro VI, o prisioneiro libertado será levado a contemplar o Sol mesmo, ao termo de sua subida até a luz. E o contemplará em face dele, contrariamente à célebre máxima de La Rochefoucauld, para quem "nem o Sol nem a morte podem ser vistos face a face". Diz Platão:

Ao final, imagino, será o Sol, e não suas imagens refletidas nas águas ou em algum outro lugar, mas o Sol mesmo, em seu verdadeiro posto, que ele poderá ver (katidein) e contemplar (theásasthai) tal como ele é (ois estín). ${ }^{16}$

\footnotetext{
${ }^{15}$ PLATÃO, República VI, 507d11-e5.

${ }^{16}$ Ibidem VII, 516b4-7.
} 
Segunda relação: a potência de ver (dunamis, 508b6), que o olho possui, é uma emanação do Sol (ósper epírruton); ela é o derivado subjetivo, na alma, da força de iluminação, de difusão da luz, que é própria do Sol.

Terceira relação: a possibilidade de o olho ver o Sol mesmo, e assim subir até a causa da visibilidade, resulta da afinidade ou semelhança que a relação precedente, relação de derivação, estabelece entre o Sol e o olho.

Quarta relação: trata-se do conteúdo da tese mesma que Platão quer demonstrar nessa análise, a saber, o Sol não é a visibilidade (o aparecer do visível), assim como também não é o olho (órgão subjetivo e seu ato), mas sua posição de fonte primeira da luz faz dele, a um só tempo, a condição dos objetos visíveis como tais e o visível por excelência.

Decifremos agora a analogia. Por ela se obtém o estatuto exato da Ideia do Bem, ou, mais precisamente, do Bem como Ideia, quer dizer, sob a relação do aparecer. Sendo a visão sensível figura do conhecimento intelectual da essência, a essas quatro condições da visão das coisas sensíveis correspondem analogicamente quatro condições da intelecção:

(1) ao olho corresponde o órgão da alma, o logistikón pelo qual os inteligíveis podem ser percebidos;

(2) ao ato do exercício voluntário da visão (orán) corresponde o conhecimento efetivo (epistéme - a ciência);

(3) aos objetos coloridos correspondem as Ideias, possuidoras, em si mesmas, de um teor de essência determinado, quer dizer, uma identidade cognoscível, aquilo que em cada uma é o pensável;

(4) à luz como reveladora e agente de atualização dessas potencialidades corresponde o que Platão nomeia aletheia.

Antes de fazer avançar nossa análise, é possível já notar que a aletheia, nessa função precisa, não é o que costumamos chamar de verdade, pois ela não é o resultado do conhecimento, mas sua condição. Platão nomeia aletheia aquilo que, no mesmo ato, permite à inteligência apreender seu objeto e ao inteligível aparecer como dado à noésis. Considerando a função que ele designa, convém então traduzir o termo aletheia por manifestação. A iluminação do visível (o qual, tomado em si mesmo, permanece obscuro) é sua manifestação; assim também, o inteligível não poderia ser conhecido se, por um lado, não houvesse certas identidades determinadas, independentes de nossas operações subjetivas, e se, por outro lado, um processo autônomo de fenomenalização, uma manifestação em ato, não as fizesse "brilhar" sob o olhar intencional.

Mas também se nota que a interpretação heideggeriana do termo aletheia, no sentido de des-velamento ou de des-cobrimento, constitui, no contexto de Platão, em uma tradução excessiva e inexata, pois a função exercida pela aletheia é iluminar o teor de sentido idêntico da Ideia e estimular 
simetricamente a aptidão do intelecto para identificar pela noésis esse teor; numa palavra, a aletheia não consiste em "des-ocultar" nem opera a partir de um estado original de dissimulação ou encobrimento. Há uma diferença importante entre o conceito de uma entidade determinada em si, anteriormente a todo aparecer, e aquele de uma entidade velada, dissimulada, ocultada: o ser-ocultado (da latência) é já um modo do aparecer, pois é um aparecer impedido, diferido, ocultado e e definido a partir de sua conversão em desvelamento. Por oposição, o que ainda não veio à luz do aparecer sequer é velado, e seu ser não poderia determinar-se em referência a um aparecer, o qual permanece, em relação a esse ser prévio, um evento perfeitamente contingente. Sem a luz, as cores das coisas e a capacidade de ver não são dados ocultos ou velados, pois não poderiam sê-lo senão com base em um parecer anterior; são somente entes inaparentes, não manifestados, e cuja possibilidade Platão não tem nenhuma dificuldade em admitir.

Se tiramos enfim a consequência dessa aplicação da analogia Sol/Bem, obtemos a determinação platônica precisa do estatudo gnoseológico e fenomenológico da ideia do Bem. Encontramos aqui, com efeito, o análogon inteligível das quatro relações que há pouco decorriam da estrutura da visão sensível.

Em primeiro lugar, vemos que é de sua relação com a Ideia do Bem que todas as outras Ideias recebem o ser inteligíveis, quer dizer, o manifestar, em uma intelecção efetiva, o teor de sentido determinado (identidade), que, aliás, reside já nessas Ideias em si, antes do ato de intelecção e previamente à manifestação. As ideias são, portanto, entes (onta) em si, mas recebem sua inteligibilidade - que é seu modo próprio de aparição - do fato de serem pensadas em relação ao Bem. Ademais, o Bem é, ao mesmo tempo, o mais inteligível, o mais claro, o mais manifesto e o mais difícil a conceber em uma intelecção estável: pelo excesso mesmo de sua evidência, ele ofusca a potência de identificação da inteligência. Ora, ao mesmo tempo e por essa mesma razão, ele não está para além do inteligível. É por isso que ele também é uma Ideia; e Platão é efetivamente bem fundamentado ao falar então (cf. 508e2) de tèn tou agathou idean, a Ideia do Bem. Ele se situa efetivamente e a um só tempo na mesma dimensão de objetividade inteligível dos outros noetá e no termo da ascensão rumo ao inteligível supremo. Donde Platão caracterizar a idea tou agathou como teleutaía, "final". Ele escreve literalmente, com efeito:

No cognoscível (en to gnósto), a Ideia do Bem é final e difícil de ver, mas, se ela é percebida (ophtheisa), dever-se-á concluir (sullogistéa) que é ela que é para todos (pasi) a causa de tudo o que é reto (orthon) e belo.

Isso já permite concluir que a intenção de Platão - sua tese - é a de que o Bem é, ao mesmo tempo, a Ideia que torna inteligíveis todas as outras 
(o berço-fonte de toda manifestação das Ideias) ${ }^{17}$ e também o objeto de intelecção, suscetível de ser visualizado por uma noésis especial, a noese mais elevada, aquela que terminaria (teleutaía) ${ }^{18}$ o conhecimento. Ela é, portanto, a Ideia mais difícil a captar por intelecção, mas a dificuldade de concebê-la, longe de ser o índice de um defeito de conteúdo ou de determinidade, deve ser interpretado, ao contrário, como o efeito de um excesso de determinidade, de uma superabundância do conteúdo pensável que ofusca a inteligência por uma evidência rica demais para ceder a uma captação distinta. A Ideia do Bem é um hiperfenômeno, um noéton essencialmente homogêneo às outras Ideias. Até aqui, o comentário feito por Heidegger é perfeitamente exato, e deve-se concluir que, como Ideia, isto é, referida à função de manifestação - pois ela é também fonte da aletheia -, a Ideia do Bem é desprovida de toda transcendência. Não é por acaso que Platão não escreve que a Ideia do Bem seria epekeina tes ideas nem epekeina tou eidous. A Ideia do Bem não tem nenhuma transcendência em relação ao inteligível se se permanece no campo ou na perspectiva da manifestação das Ideias. Mas, justamente, Platão não se restringe apenas a essa perspectiva; ele visa também, tanto no caso do Bem como no caso do Sol, a outro tipo de causalidade, para além da produção de luz ou aletheia. É precisamente no contexto dessa nova abordagem, regida por uma problemática inteiramente diferente daquela do aparecer e da manifestação, que Platão emprega a célebre fórmula epekeina tes ousias. Citemos a passagem decisiva:

- Tu concordarás, penso eu, que o Sol dá às coisas vistas (oroménois) não somente a capacidade de serem vistas (ten tou orasthai dúnamin), mas também geração (génesin), o crescimento e a nutrição, sem ser ele mesmo geração (génesin).

- De fato, como poderia ele o ser?

- Concorde, então, que às coisa conhecidas (gignoskoménois) o Bem dá não somente o fato de serem conhecidas (to gignoskésthai), mas também de terem a partir dele o ser ( $k a i$ to einai) e a essência (kai ten ousian), ainda que o Bem não seja essência (ouk ousias ontos tou agathou), mas ultrapasse para além da essência (epekeina tes ousias uperechontos) em dignidade e em força (dunamei) ${ }^{19}$

Assim como o Sol não é apenas berço de luz - fonte de manifestação mas efetua também uma segunda operação, gerativa (porque ele é causa da formação, do crescimento, da nutrição e do devir dos entes sensíveis), assim também Platão põe em evidência uma segunda função, propriamente causal, do Bem, o que faz dele a fonte do ser e da essência de tudo o que é ousia, do ser dos onta que são os inteligíveis. O Bem, então,

\footnotetext{
${ }^{17}$ Nesse sentido, ela é efetivamente, como sublinha Heidegger, "verdade soberana e aquela que permite a inteligência" (kuría aletheía kaí noun paraschoméne - 517c4).

${ }^{18}$ Essa palavra tem por raiz o termo teleios: perfeito, completo, acabado.

${ }^{19}$ PLATÃO, República VI, 509b1-10.
} 
deve ser reconhecido como "para além" ou "acima" da ousia ou do reino das essências inteligíveis justamente como princípio gerador do ser e do conteúdo daqueles onta que são as essências em si - "entes" no sentido mais próprio e forte. O Bem como origem e causa da ousia não é mais, agora, uma Ideia entre outras Ideias (nem mesmo a Ideia final!); ele não se situa mais no mesmo plano homogêneo aos outros onta. Assim, apenas as Ideias diferentes do Bem são essências ou têm uma essência, ousia. Platão incita, assim, a pensar o Bem como "mais alto em dignidade e força" do que a sua própria ousia e ser.

Disso resultam três consequências importantes. Primeira: o Bem é, sem dúvida, objeto de uma visada intelectual possível. Na ordem da manifestação (aletheia), ele é efetivamente o berço da inteligibilidade que irradia aliás sobre ele mesmo, de maneira que ele se mostra em sua própria luz. Como hiperfenômeno, o Bem é, assim, idea tou agathou, Ideia do Bem, ou, mais precisamente, se se explicita o sentido preciso dessa expressão, ele é o Bem sob a forma de sua automanifestação, ou ainda, o-Bem-que-se-apresenta-em-sua-própria-visibilidade. Mas ele não poderia, aos olhos de Platão, reduzir-se a essa única condição. O Bem não se esgota em seu próprio fenômeno (em sua idea). É preciso, então, ousar a hipótese de que o Bem mesmo transcende sua própria Ideia; ele "é" de um modo que, radicalmente e por princípio, ultrapassa toda possibilidade de fixação de uma identidade tal como se opera na intuição ideadora. ${ }^{20}$ Sem dúvida, essa é, aliás, a razão pela qual, quando o texto da República aborda sua segunda perspectiva (o Sol e o Bem como princípios de geração), a expressão idea tou agathou desaparece: Sócrates não fala mais de "Ideia do Bem", mas simplesmente de "Bem", declarando que ele não é essência: ouk ousias ontos tou agathou.

Segunda consequência: percebe-se claramente agora o erro implicado na interpretação de Heidegger, qual seja, o de deixar em silêncio a radical diferença que caracteriza a segunda perspectiva introduzida por Platão, aquela da causalidade mostrada pelo Bem mesmo, diferentemente de sua Ideia. A ilusão produzida por Heidegger consiste em identificar inteiramente o Bem platônico à sua função fenomenalizante, como se o agathon só tivesse um papel ontologicamente decisivo no campo da aletheia, quer dizer, da manifestação dos entes conhecidos. Mas Platão considera que tais entes conhecidos ( ta gigno skomena) não se limitam ao serem-conhecidos; é preciso que sejam (einai) - no caso dos inteligíveis - ou que sejam engendrados (genesis, genesthai) - no caso dos sensíveis. É essa distinção platônica, firme e clara no texto, entre o ponto de vista da fenomenalidade/fenomenali-

\footnotetext{
${ }^{20}$ A noção de "intuição ideadora", tal qual redescoberta e sistematicamente explorada por Husserl do ponto de vista metodológico e gnoseológico na elaboração do método fenomenológico, é indispensável aqui para seguir, ainda que de maneira pouco concreta, a estrutura lógica do pensamento de Platão.
} 
zação e aquele da causalidade como vinda-ao-ser, que Heidegger oculta ao dar a entender que o estatuto ontológico do Bem coincide com aquele da sua ideia, vista unicamente como "Ideia Suprema". Ora, contratriando essa leitura uniformizante que recusa (como bem lembra Franco Trabattoni $)^{21}$ o estatuto de objeto transcendente ao Bem platônico, encontra-se em Platão uma dissociação clara entre a ontologia (mais precisamente a ousiologia) e a fenomenologia como doutrina das condições do aparecer. Platão distingue, com efeito, entre a imanência própria da "Ideia" do Bem, segundo a ordem da intenção da intelecção como fenomenalidade, e a transcendência que pertence, segundo a ordem do ser, ao Bem mesmo. É precisamente por essa razão que a doutrina platônica do agathon não podia integrar-se, sem deformá-lo seriamente, ao projeto heideggeriano de uma elucidação fenomenológica do ser centrada na dimensão exclusiva da aletheia. Convém notar que essa distorsão, assim como a correlativa segregação da transcendência ontológica do Bem, tem um preço bastante alto mesmo para a problemática heideggeriana: Heidegger distancia-se daquilo que constitui o momento especificamente ontológico do pensamento de Platão. Com efeito, se se buscasse em Platão um contexto em que apareça com a maior clareza o sentido do ser (to einai) como parousia, seria aqui que se poderia encontrar. $\mathrm{O}$ texto platônico diz inequivocamente:

kai tois gignoskomenois toinun me monon to gignoskesthai phanai upo tou agathou pareinai, alla kai to einai te kai ten ousian up'ekeinou autois proseinai, ouk ousias ontos tou agathou, all'eti epekeina tes ousias presbeia kai dunamei uperechontos (...)..22

Terceira consequência e conclusão mais interessante: uma tarefa hermenêutica nova impõe-se-nos a partir dessas observações, qual seja, investigar em que sentido minimamente concreto convém compreender que o Bem mesmo - independentemente de seu aparecer em uma visada intelectiva - é causa do ser dos inteligíveis e da ousia deles, assim como causa deles, ou sua arche, sem ser ele mesmo uma essência nem ter essência?

\section{III ón, ousia, agathon}

Muitas passagens do corpus dos diálogos permitem esclarecer a primeira questão, aquela do modo como o Bem é causa. Por razões de brevidade, concentremos no célebre texto de Fédon 97b8-99e, no qual Sócrates explica

\footnotetext{
${ }^{21}$ Cf., por exemplo, TRABATTONI, F. Heidegger e l'idea platonica del Bene: storia di una amicizia fallita. Chôra. Revue d'études anciennes et médiévales 2017/2018 (15/16), p. 591-610. 22 "O mesmo dirás dos objetos conhecidos, que não recebem do bem apenas a faculdade de serem conhecidos, mas também the devem o ser e essência, conquanto o bem não seja essência, senão algo que excede de muito a essência em poder e dignidade." (PLATÃO, República VI, 509b6-9. trad. Carlos Alberto Nunes: Diálogos de Platão. A república. Belém: ed.ufpa, 2016, 4ํㅡㄹ ed. revisada e bilíngue).
} 
a Cebes os motivos de sua decepção diante da teoria do nous desenvolvida por Anaxágoras.

A compreensão determinada dessa relação exige, entretanto, que se precise, antes de tudo, o sentido grego de alguns conceitos fundamentais, tais como empregados por Platão no contexto das passagens da República já citadas aqui, particularmente os conceitos de on (ente), ousia (essência) e agathon (bem).

\section{O sentido de ón}

O sentido primeiro de on e einai, no grego de Platão, não deve ser entendido a partir da noção, muito mais tardia, de "ser", no sentido de existência, como sinônimo de realidade ou efetividade. Isso se verifica pelo fato de que, correlativamente, a expressão me on, em Platão, não designa o nada, o nihil negativum de $\mathrm{Kant}^{23}$ ou a ausência pura e simples de todo ente. Em vez disso, me on designa aquilo que se furta à predicação ou aquilo de que não se pode pensar: "tal ou qual" ou "este ou aquele".

No sentido empregado por Platão, einai significa sempre implicitamente einai ti, donde essa primeira tese ou definição: o on platônico tem seu primeiro sentido não a partir de alguma angústia diante do nada, nem a partir da experiência da temporalidade, mas a partir da exigência da predicação. Ser, no sentido platônico, é ser-determinado, possuir uma determinação própria, enunciável sob a forma daquilo que a lógica medieval caracterizará mais tarde como praedicatum. O critério original da qualidade ou dignidade do on, portanto, não é tanto a persistência transtemporal de um Vorhanden ou de uma "presença que perdura" (Ständigkeit des Seins), tal como concebida por Heidegger, mas a possibilidade de determinar a coisa (pragma) segundo a predicação. Trata-se fundamentalmente da experiência grega do logos do que está em questão; do dizer "o que é". O conceito platônico de on é a substantivação gramatical da proposição (pelo caminho do particípio presente de einai, que faz de ser - entendido como relação de predicação, no sentido de "ser isto" - um nome): o ti esti [touto], o que é [isto]. Tal uso semântico revela o conceito diretor fundamental que subjaz na compreensão grega (ao menos platônica) de on, qual seja, o de identidade. Essa observação permite compreender melhor dois traços aliás surpreendentes, para nós, do discurso de Platão sobre o on.

Em primeiro lugar, há graus no einai. A Alegoria da Caverna, em particular, distingue entre os mais ou menos onta. Essa possibilidade de múltiplos

\footnotetext{
${ }^{23}$ Cf. a tábua das quatro figuras do nada na Crítica da razão pura, Analítica Transcendental, Livro II, Apêndice, "Anfibologia dos conceitos da reflexão".
} 
graus na maneira de justificar a qualificação como on não pode ser compreendida a partir de um conceito ontológico ou existencial do ser; ela se refere à maior ou menos variabilidade de determinações que permitem caracterizar, de maneira própria e diferenciada, o objeto visado.

Em segundo lugar, aproximar-se cada vez mais do on, e mesmo do ontos on, à medida que se toma distância do domínio do devir e que se acede aos objetos que são agéneta ou não submetidos à geração/geração, não significa que o sensível em devir, por causa de sua mutabilidade, é desprovido de realidade ou existência. Afinal, a sombra, o reflexo ou a coisa sensível e sujeita à mudança não são um nada; eles têm uma realidade, e, nesse sentido, tanta efetividade quanto o eidos, que compartilha com eles a mesma condição de objeto-de-um-olhar. Essa tese platônica é esclarecida a partir da constatação de que a mudança (kinesis) põe em xeque o projeto de determinação de uma identidade, suscetível de ser retomada tal qual em um logos. É sua não-identidade a si, e não a pluralidade como tal, que desqualifica o múltiplo e obriga a situar o sensível na classe dos me onta (se se retém o sentido forte de on) ou ao menos naquela dos menos onta.

\section{O conceito de ousía}

Dito isso, compreende-se melhor também o sentido do par on/ousia.

O termo ousia designava originalmente os bens ou as posses de alguém (seu patrimônio móvel). Em Platão, ousia é uma metáfora para designar o teor-de-sentido ou o conteúdo-de-determinações que confere um caráter de identidade determinada justamente à coisa (pragma) a respeito da qual se pode dizer "é". Assim, ousia designa originalmente em grego o mesmo que pretende exprimir o termo alemão Bestand: a um só tempo, as "subsistências" ou o que resta para constituir o fundo, o estoque das posses que identificam um indivíduo como proprietário a partir de seu patrimônio, e o conteúdo no qual consiste (besteht - esti) essa identidade patrimonial, quer dizer, o teor em determinidades graças ao qual se pode dizer da coisa em questão: "é isto" ou "é aquilo".

\section{O sentido do agathon}

Como lembra muito corretamente Franco Trabattoni ${ }^{24}$ Heidegger precisa que, no seu dizer, não se deve entender o termo agathon em sentido ético. Para cortar pela raiz toda tentativa de interpretação que desembocasse em

${ }^{24}$ Cf. o artigo supracitado. 
uma "filosofia dos valores" - pela qual ele sempre mostrou uma repugnância explícita -, Heidegger defende que a Ideia do Bem entra na categoria da dunamis. Ele propõe, assim, no ensaio de 1940/42/47, intitulado A doutrina platônica da verdade, traduzir agathon por das Tauglichmachende, literalmente: "aquilo que torna apto para..."; portanto, "aquilo que funda a possibilidade de outra coisa". ${ }^{25} \mathrm{O}$ agathon platônico recebe, assim, o sentido de simples "fundamento da possibilidade", ${ }^{26}$ e, como constitutivo de sua essência, encontra-se, portanto, a noção de dunamis. Essa concepção puramente relacional do Bem consiste, definitivamente, em abolir a absolutidade do Bem, que se torna não mais "o Bem" em si, absolutamente falando, mas o caráter de ser "bom para..." ou "bom de...", ou ainda, segundo os termos do curso heideggeriano de 1928, aquilo "em vista de que", to on eneka. O Bem deixa, assim, de implicar e de fundar uma avaliação; ele se esgota na relação estabelecida entre as Ideias. Com efeito, Heidegger escreve:

Cada Ideia ou e-vidência de um coisa permite a visão disso que é a coisa considerada. Assim, para o pensamento grego, as "Ideias" tornam apto a isto: que uma coisa possa aparecer naquilo que ela é e possa ser assim presente no que ela tem de permanente. As Ideias são, em cada ente, aquilo que é. Assim, aquilo que torna cada Ideia apta a ser uma Ideia, quer dizer, em linguagem platônica, a Ideia de todas as Ideias, consiste em tornar possível a aparição de todas as coisas presentes em sua inteira visibilidade. A essência de toda ideia reside em permitir parecer, em tornar apto a esse parecer que dá uma vista sobre a e-vidência. ${ }^{27}$

Essa compreensão do agathon suscita duas objeções principais: primeira, agathon, em grego, não significa nunca "apto para...", pois isso se diz ikanon, nem significa "o que torna apto" ou "o que torna possível", pois isso se diria to ikanon (ou dunaton) poioun, ou ainda to parechomenon; segunda, o texto platônico emprega sempre a forma substantivada do adjetivo agathos, $-e$, -on, em estreita correlação com o uso comparativo ou superlativo desse adjetivo.

Convém, então, começar por lembrar que to agathon nunca significou "o bem". Nas línguas latinas modernas, "o bem" é a substantivação de um advérbio de modo, e não o adjetivo correspondente. Em grego, o advérbio "bem" se diz eu. Se Platão quisesse designar como ideia ou princípio "o Bem", ele teria escrito to eu, como se encontra, por exemplo, na língua da ética de Aristóteles (to eu dzen; to eu prattein). Mas, Platão não designa, em nenhuma passagem, a Ideia suprema como idea tou eu nem como identificável a algo como to $\mathrm{eu}$, construções inteiramente alheias à sua

\footnotetext{
${ }^{25}$ Cf. HEIDEGGER, M., Questions II, op. cit., p. 149-150: "Para o pensamento grego, to agathon significa aquilo que é apto a algo. (...) A expressão ‘Ideia do Bem', tão adequada para desviar os intérpretes modernos, é o nome dessa Ideia privilegiada que, como Ideia das Ideias, é, para tudo, aquilo que torna apto (das Tauglichmachende)."

${ }_{26}$ Ibidem, p. 150: "O Bem (...) é a ideia mais elevada como fonte de possibilidade".

${ }^{27}$ Ibidem, p. 149, parágrafo 3.
} 
língua filosófica. Com efeito, no texto platônico não se trata jamais do "Bem", mas justamente e por toda parte do "Bom", constantemente em uma perspectiva avaliativa, expressa em termos de "melhor" ou de tensão para um estado melhor (ameinon), excelente (ariston; beltiston).

Isso é particularmente evidente na passagem do Fédon cuja referência ${ }^{28}$ já anunciamos aqui e que é uma das melhores fontes para determinar o conceito platônio de agathon:

Tendo ouvido um dia alguém ler em um livro de Anaxágoras que a inteligência (nous) é o ordenador (diakosmon) e a causa (aitios) de todas as coisas, encantei-me com essa causa (aitia) e pareceu-me que, de algum modo, era perfeito (eu echein) que a inteligência fosse a causa de tudo; e eu pensava que, se é assim, a inteligência ordenadora ordenava tudo (panta kosmein) e punha cada coisa (ekaston tithenai) da maneira que mais convinha a cada coisa (ope an beltista eche). Se, então, se quiser encontrar, a respeito de cada coisa, a causa em virtude da qual ela nasce ou perece, ou é, deve-se procurar, concernente a cada coisa, como é melhor para ela ser ou padecer ou produzir (einai, paschein, poiein) alguma outra coisa. Desse raciocínio (logou) decorria não ser conveniente ao ser humano, tanto no que toca a ele mesmo quanto no que toca aos outros, procurar nada que não seja o melhor e o mais excelente. ${ }^{29}$

O contexto de onde é tirada essa citação demasiado breve - mas já muito eloquente pela frequência mesma das expressões avaliativas, nas quais o bom é concebido sob a forma comparativa "melhor que" ou superlativa "o melhor"/"o mais excelente" - é bastante conhecido: trata-se, para Sócrates, de encontrar uma resposta satisfatória à questão da causa concernente às realidades físicas e cosmológicas. Seu entusiasmo imediato com a tese anaxagórica deriva diretamente dessa orientação temática em direção do problema da "causa de todas as coisas". Assim, depois da passagem que acaba de ser citada, Sócrates precisa ainda uma vez:

Essas reflexões então me deixavam bem à vontade: dava-me conta de ter encontrado o homem capaz de me ensinar a causa dos entes (didaskalon tes aitias peri ton onton), a qual seria para mim (emauto) conforme à inteligência (kata noun). ${ }^{30}$

O objetivo perseguido por Platão em toda a passagem (97b-99d) é explícito: ele se aplica em mostrar a insuficiência radical de que sofre, no tocante à exigência de definir a causa da ordem cósmica e das determinações das coisas naturais, toda explicação de tipo físico que não sabe reconduzir o efeito observado senão a condições materiais: trata-se de uma falta de inteligibilidade. A causalidade simplesmente física não pode apreender

${ }^{28}$ Cf. PLATÃO, Fédon 97b8-d2.

${ }^{29}$ Ibidem, $97 \mathrm{~b} 8$ - d 2

${ }^{30}$ Fédon 97d5-7. 
mais do que as condições que tornam possível a disposição das coisas; ela não pode identificar o fator que a torna ncessária, quer dizer, o motivo último em razão do qual, entre todos os arranjos materialmente possíveis, é precisamente "este" arranjo que deve ser realizado. O fundamento inquebrantável da objeção de Platão a toda interpretação fisicista do cosmo reside na identificação que ele opera entre inteligibilidade e necessidade: é somente com a condição de aparecer como necessário que a ordem do mundo pode tornar-se inteligível. A contingência física é uma forma de irracionalidade com a qual a inteligência não pode contentar-se, a menos que falte com a seriedade e não tenha nenhum escrúpulo em relação à linguagem. ${ }^{31}$

Em uma terminologia mais moderna, poder-se-ia dizer que a razão física mostra-se assim insuficiente. Esse célebre texto constitui a primeira formulação clara do princípio de razão sucifiente, e seu sentido é pôr em evidência aquilo que Leibniz nomeará precisamente "o princípio do melhor". Ora, observa-se que o bom - sob a forma do melhor, relativo ao absoluto - comparece aí efetivamente como causa do ser e dos entes, e não somente como condição de possibilidade da sua manifestação (aletheia) ou do conhecimento de suas ideias, como pretendia a interpretação heideggeriana.

Objetar-se-á talvez que, nas páginas citadas, não se trata, propriamente falando, do agathon mesmo ou segundo o modo como o apresentam os livros VI e VII da República. Mas essa objeção é inexata, pois, ao contrário, Platão estabelece nesse texto preciso do Fédon uma ligação direta entre o uso explicativo do "melhor", por uma teleologia física, e a noção de "bom", agathon. É essa ligação que autoriza a aproximação das páginas do Fédon com a teoria do "Bem" desenvolvida na República. Em 99c, escreve Platão a respeito dos "físicos" que tomam condições favoráveis por causas:

Quanto à potência por cuja ação a melhor disposição possível (os oion te beltista) para essas coisas é de fato realizada (nun keisthai), eles não a procuram (...); eles pensam poder descobrir um dia algum Atlas mais forte do que este, mais imortal, e pelo qual todas as coisas (apanta) seriam sustentadas ainda mais juntas (sunechonta); e eles não pensam de modo algum (ouden oiontai) que o que as junta (sundein) e as mantém (sunechein) é aquilo que é autenticamente (os alethos) bom e adequado (to agathon kai deon). ${ }^{32}$

\footnotetext{
${ }^{31}$ Cf. especialmente 99b1-2.

${ }^{32}$ Ibidem, 99c1-6: PLATÃO. Phédon. Trad. Léon Robin. Paris: Belles Lettres, 1936. Trad. modificada por J.-F. Lavigne. Note-se que Léon Robin assinala corretamente aqui um jogo de palavras significativo para Platão: o filósofo aproxima o verbo dei ("é preciso que...", "é necessário que...", donde derivam o particípio presente déon, aqui substantivado como to deon) e o verbo homônimo deo, "unir", "juntar", do qual ele se serve para designar a ligação coerente de todas as coisas no seio do cosmo. Essa aproximação verbal (análoga às etimologias do Crátilo exprime então a ideia de que é a necessidade do dever-ser que, ligando os entes, forma a estrutura coerente do todo (apanta). Cf. PLATÃO, Phédon, op. cit., Notice, p. XLVIII, nota 1.
} 
Vários elementos fazem dessa passagem um texto altamente significativo para nossa pesquisa. Em primeiro lugar, Platão designa aqui explicitamente "o Bom" (to agathon) como princípio, e não a sua "Ideia". Não é a "Ideia do Bem" que é causa; e "o Bom" tem o papel de princípio causal autêntico. Além disso, e sobretudo, Platão não separa a noção de agathon daquela de deon, quer dizer, da noção de "o que é adequado", o que convém", "o que se deve", "o que deve ter lugar em virtude de uma necessidade objetiva". ${ }^{33}$ Se o "Bom" é causa, e mesmo se, no Fédon, ele é o único princípio causal verdadeiramente inteligível, é porque ele é pensado como dever-ser e porque nele se funda assim uma necessidade teleológica. Não é correto, portanto, separar aqui o conceito de "melhor" daquele de agathon como tal: o agathon não pode desdobrar, com efeito, a potência explicativa de uma causa determinante senão na medida em que ele opera como a potência teleologicamente motivante e capaz de tornar necessária a ordem natural e, por conseguinte, na medida em que ele é concebido como dever-ser, como aquilo que deve ser realizado (deon) para que cada coisa chegue à determinação ou se complete como identidade determinada. É verdade que não se pode encontrar, nesse contexto platônico, uma "filosofia dos valores", mas, em revanche, é preciso admitir que a noção platônica de agathon implica uma avaliação, pois ela fundamenta um julgamento em termos de "melhor" e "pior". Além disso, essa noção instaura inegavelmente uma finalidade teleológica, longe de deixar-se reduzir ao estauto meramente relativo de um simples fator possibilizante, como queria Heidegger.

O "Bom", agathon, remete, então, nesses textos do Fédon, a uma identidade teleológica interna que, concebida como o dever-ser próprio de uma coisa, constitui a norma imanente dessa coisa, de modo que se deve entender to agathon como designativo do fim essencial próprio cuja realização constitui, para uma coisa, o mais perfeito cumprimento de sua identidade.

\section{O Bem como causa do ser}

As precisões conceituais aqui feitas permitem apreender, de maneira mais adequada, o significado exato da tese platônica de que o agathon, ao mesmo tempo, é causa do ser das Ideias e está para além da essência.

É verdade que seria possível levantar ainda uma objeção contra o princípio mesmo desse método de interpretação: ele supõe, com efeito, que as

\footnotetext{
${ }^{33}$ Reconhecemos que traduzir deon por "adequado" ou "conveniente" é um pouco fraco. No entanto, traduzi-lo por "necessário" introduz uma dimensão metafísica excessiva e comporta diferentes equívocos. Para os gregos, deon é o que é adequado fazer, o que convém fazer, porque se trata de uma obrigação, um dever-ser.
} 
posições doutrinais defendidas por Platão no Fédon são pertinentes para iluminar os textos ontológicos fundamentais da República. Seria legítimo explicar um diálogo por um outro? Isso não significaria postular rápido demais uma unidade e uma constância na filosofia de Platão, desmentida no entanto em diferentes casos pela comparação dos diálogos, seja no tocante ao conteúdo doutrinal seja no tocante ao método?

Com efeito, seria absurdo, no estado atual de nossos conhecimentos filológicos e históricos a respeito da evolução mais provável do corpus platônico, não reconhecer, entre os primeiros diálogos ditos "socráticos" e os diálogos mais sistemáticos ditos "de maturidade", disparidades estilísticas, metodológicas e temáticas. A principal dessas disparidades, e a mais evidente, é precisamente a elaboração da teoria gnoseológica e ontológica das Ideias ou Formas (ideai/eide).

Todavia, também não se pode negar que aparece, com o grupo particularmente coeso e formado pelos diálogos Teeteto, Parmênides, Sofista e Político, uma problematização radical, intensificada de outra maneira, da doutrina platônica anteriormente constituída e centrada na teoria das Ideias e no duplo movimento do conhecimento dialético tal como contido justamente na Alegoria da Caverna. Mas, precisamente, as dúvidas e a circunspeção crítica que justificam essas disparidades não concernem às relações entre o Fédon e a República. De uma parte, com efeito, o parecer bastante geral dos especialistas (com base em numerosas aproximações temáticas e conceituais às quais eles se prestam) considera que esses dois diálogos pertencem ao mesmo período de "maturidade", posterior à grande viagem de Platão ao Egito, Sicília e Magna Grécia, bem como à criação da escola do parque de Acádemos (388 a.C.). De outra parte, do ponto de vista interno, essa proximidade cronológica é confirmada pela maneira como o Sócrates do Fédon apresenta apresenta e desenvolve a teoria das Ideias: na passagem em que Sócrates explica a Cebes a orientação metódica por ele adotada depois da decepção causada pela leitura de Anaxágoras, Platão sublinha com insistência o caráter habitual, familiar e mesmo trivial dessa teoria nos discursos de Sócrates. Com efeito, em 100a7-b5, lê-se:

- Mas quero expor-te mais claramente o que acabo de dizer, pois tenho a impressão de que por enquanto tu não compreendes.

- Por Zeus, diz Cebes, não muito bem!

- No entanto, retoma Sócrates, essa maneira de falar não é nem um pouco nova (ouden kainon); ao contrário, é ela que tenho empregado sempre (ouden pepaumai legon), assim como na última argumentação. Assim que termino de tentar explanar-te qual é a espécie de causalidade à qual eu me aplicava com tanto esforço, eis que eu reencontro (kai eimi palin ep'ekeina) aquilo que, como é sabido, já remoí mil vezes (ta poluthruleta): isso me serve de ponto de partida 
e de fundamento, pois admito que há um um Belo em si e por si, um Bom, um Grande e assim por diante. ${ }^{34}$

Apresentando com tanta insistência e de maneira tão explícita a doutrina das Ideias, tal como formulada no Fédon, como exposição reiterada de uma teoria constante e regularmente retomada por Sócrates - a ponto de ela se ter tornado familiar para seus ouvintes habituais e característica do ensinamento socrático -, Platão indica com a máxima clareza que não convém fazer diferença, nem de conteúdo nem de significado, entre a exposição detalhada da teoria do inteligível ideal em si que se elabora na República (e se desenvolve em Banquete e Fedro) e a sua reprise resumida (apresentada quase como doxográfica) no Fédon. Esses índices concordantes, externos e internos, autorizam, ao que tudo indica, tratar a teoria das Ideias apresentada na República e aquela exposta por Sócrates no Fédon como expressão de um único e mesmo pensamento, simplesmente modulado ou ampliado, nesse último diálogo, pela consideração da questão cosmológica, que não podia aparecer como central no contexto ético-político da República.

Descartada, assim, a objeção metodológica, retomemos nossa questão principal, que é o ponto decisivo para a apreciação da interpretação heideggeriana: como compreender a tese segundo a qual o agathon, ao mesmo tempo, é causa do ser das Ideias e está para além da ousia?

Deixemo-nos ainda guiar, conforme à escolha metodológica de Platão, pela analogia da intelecção e da visão sensível. O Sol, difundindo a luz, é a fonte da manifestação das coisas sensíveis em sua determinidade cromática, que é sua identidade própria (relativa), segundo a ordem do visível: nisso ele é causa da visibilidade delas, de sua cognoscibilidade específica como coisas sensíveis, mas não do ser delas (o qual, nessa ordem do sensível, é um devir); porém, além disso, o Sol é também o princípio da geração/ crescimento/devir delas, porque é ele que, como fonte de energia cósmica e vital, faz nascer e desenvolver-se tudo o que vive e existe: ele torna cognoscível pela visão aquilo que, mesmo fora da visão, ele faz existir e durar no devir. Sua causalidade ontológica é principialmente distinta de sua potência de fenomenalização, que é gnoseológica, embora uma e outra apliquem-se aos mesmos objetos, as coisas sensíveis naturais. Isso significa, de saída, que a causalidade ontológica exerce-se antes e independentemente da relação cognitiva: não é iluminando as coisas que o Sol as faz nascer ou vir ao seu ser; e o texto platônico distingue muito claramente a "capacidade de serem vistas", por um lado, e a "geração, crescimento e nutrição", por outro: ${ }^{35}$ Platão não subscreve um idealismo fenomenoló-

${ }^{34}$ PLATÃO, Fédon 100a7-b5 (Ed. Robin, p. 73). Trad. modificada por J.-F. Lavigne. Note-se aqui a menção ao agathon, o Beom, entre as realidades "em si", transformadas por Sócrates em um tema "trivial" de seus debates.

${ }^{35}$ Cf. PLATÃO, República VI, 509b1-10. 
gico segundo o qual o ser se confundiria com o aparecer (e se resumiria nele). E certo que, para tornarem-se manifestas e serem conhecidas, não basta que as coisas sensíveis sejam engendradas; requer-se ainda que a luz seja projetada sobre elas. Porém, inversamente também, a iluminação não pode fazer mais do que tornar manifesto o que já existe por já ter sido engendrado antes e em virtude de outro processo. Trata-se da clara dissociação das duas relações - causalidade ontológica e fenomenalização cognitiva - que permite compreender como o mesmo Sol pode, a um só tempo, segundo a ordem do aparecer, pertencer ao domínio do visível (ele é, com efeito, o visível mais elevado, pois, como fonte da luz, ele se automanifesta autoiluminando-se) e transcendenr, por seu modo de ser, o domínio daquilo mesmo que ele torna manifesto. Afinal, as coisas sensíveis que o Sol ilumina surgem e perecem, ao passo que o Sol (para Platão como para toda a astronomia antiga) não devém, mas permanece eternamente:

(...) o Sol dá às coisas vistas (oromenois) não somente a capacidade de serem vistas, mas também a geração, o crescimento e a nutrição, sem ser ele mesmo geração (genesin). ${ }^{36}$

O que permite determinar o significado do epekeina tes ousias é esse sistema de relações que indica de modo analógico, na intenção de Platão, a estrutura do duplo vínculo que liga o Bem ao inteligível. Comecemos por estabelecer, a esse respeito, uma compreensão simplesmente formal.

Nesse primeiro nível, a analogia dá a entender que, do ponto de vista do conhecimento, somente a qualidade de "Bom", tomada em si mesma e universalmente, permite perceber intelectualmente a Ideia como on, quer dizer, a identidade unitária determinada que forma o teor identicamente cognoscível de cada coisa: é apenas a referência teleológica à excelência, ao "Bom" como tal, que pode fornecer a razão suficiente da identidade determinada do ente, porque é somente ela que manifesta a necessidade do ente. Com efeito, perceber o teor em propriedades de um ente como necessário em si não é possível a não ser que liguemos esse teor a uma razão de ser última, que não pode ser, para Platão, senão finalidade. Mas, na contrapartida, a recondução das determinidades do ente ao fim último que funda a necessidade delas tem por efeito manifestar esse ente como possuidor de um sentido. É esse sentido, de essência fundamentalmente teleológica, que confere então ao teor em propriedades do ente em questão o caráter de uma identidade una, estável e própria; numa palavra, de uma essência, a dignidade disso que Platão entende, em sentido forte, por on. Assim, sob uma primeira relação, que é aquela do conhecimento, a relação do Bom em si com as identidades determinadas consiste em fazer que a inteligência as perceba, ou seja, em torná-las inteligíveis, manifestas em

${ }^{36}$ Idem, ibidem. 
seu caráter de evidência intelectual, fundando-as teleologicamente como sentido.

Todavia, a estrutura da analogia platônica significa também que a relação do Bom, tomado em si, com essas identidades de sentido não pode limitar-se à manifestação cognitiva delas: é preciso pensar o Bom como causa do ser mesmo dessas identidades, consideradas agora não mais como objetos intencionais de uma captação intuitiva possível - como eide ou ideai -, mas fora de toda relação de conhecimento e antes de toda fenomenalização, quer dizer, como identidades determinadas e subsistentes independentemente de toda evidência subjetiva ou do fato de serem ousiai, essências. Surge então, a questão: como conceber essa causalidade? Como compreender agora que o Bom ideal, a orientação tendencial rumo ao melhor, é o que faz que essas identidades sejam sem mesmo que elas, para serem, tenham necessidade de tornarem-se inteligíveis?

Ultrapassemos agora a interpretação simplesmente formal.

É aqui que convém lembrar o sentido grego original de ser/einai: não se trata de existir, no sentido da presença arrancada a um possível nada, mas de ter uma identidade própria determinada, um ser-tal. Ademais, a relação que se procura definir agora na ordem das essências possui seu analogon sensível na alegoria da visão: enquanto o Sol, manifestando as coisas pela iluminação de suas cores, torna-as cognoscíveis à visão e, com ainda maior evidência visual, mostra-se ele próprio a arche de tal visibilidade, esse processo de iluminação não manifesta de maneira nenhuma a operação gerativa que o mesmo Sol cumpre todavia no mesmo instante e que, em relação às mesmas coisas assim tornadas visíveis, ele já cumpriu previamente. A relação ontológica de engendramento não aparece no campo daquilo que manifesta a relação gnoseológica de manifestação, e ela não precisa fazê-lo. Ela permanece secreta, absolutamente inapercebida, imperceptível ao olhar: eu vejo as coisas sensíveis, mas a geração natural delas pela força cósmica do Sol é e permanece necessariamente, por si, invisível. Ainda, a respeito da relação entre o Bom ou o Melhor como princípio e as identidades ideais, deve-se dizer justamente que, para ser, a relação pela qual o Bom faz das identidades ideais ousiai não tem de aparecer no campo de uma visada intelectiva. Convém compreender, portanto, a relação causal do Bom com as essências como uma relação de fundação invisível, quer dizer, não fenomenal e absolutamente independente de toda fenomenalização. Por outro lado, na medida em que ser significa aqui ter uma identidade determinada, essa causalidade do Bom - mais precisamente a operação pela qual o Bom mesmo, em si mesmo e por si mesmo (e não mais sua Ideia ou seu aparecer inteligível na evidência intelectual) conduz ao einai o conteúdo pensável desses objetos - é a relação de fundação-justificativa teleológica pela qual eles recebem dele o caráter de identidades necessárias, absolutamente justificadas e constantes, relação reconhecida como 
originariamente anterior a toda manifestação, como estrutura absoluta $e$ absolutamente autônoma.

Para dizer de maneira mais simples, Platão é um pensador para quem as coisas são o que elas são não por um efeito do acaso (que tornaria a identidade delas provisória e fortuita, o que é absurdo), nem pelo efeito de uma causalidade física sem fundamento (o que é igualmente absurdo), mas porque essa identidade determinada, assim como o sistema universal das relações que ela acarreta e determina no todo do cosmo, é boa ou conforme ao princípio da maior perfeição. Mas, sobretudo, Platão é esse pensador para quem a ordem da maior perfeição é uma estrutura absoluta e absolutamente incondicionada. $\mathrm{O}$ fato de uma identidade determinada ser reconhecida com evidência como boa não implica que ela deva ser julgada tal, mas, ao contrário, se ela é boa em si e por si, ela pode eventualmente aparecer tal em um conhecimento intuitivo, cosmológico, ético ou político. O Bom é causa das essências por ser o ideal teleológico em relação ao qual toda identidade determinada pode receber a fundação de seu conteúdo e sua necessidade.

Essa decifração da analagia do final do livro VI da República permite, assim, definir o sentido preciso da transcendência do Bem em relação às essências. Assim como o Sol engendra as coisas sensíveis e sujeitas ao ciclo da geração e do devir, sem ser ele mesmo engendrado nem sujeito ao devir, o Bom em si, em sua fundação teleológica da identidade das essências ideais, situa-se necessariamente para além da essência em dignidade e em potência, pois ele não poderia partilhar a condição ontológica das identidades ideais que ele funda.

Essa transcendência em relação ao domínio das essências tem, então, diferentes significados. Primeiro, ela significa que o Bom não é uma essência. Com efeito, ele não pode ter o caráter e a estrutura de uma identidade determinada: por um lado, como telos finalizante, ele não pode definir-se por um conteúdo limitado que seria exclusivo de outros conteúdos possíveis; por outro lado, como princípio universal de avaliação e justificativa, ele é necessariamente distinto do conjunto dos objetos cuja avaliação ele funda e externo a esse conjunto. O Bom não pode, portanto, ter uma identidade nem ser uma entidade ideal entre as outras; é nesse sentido que é justo declará-lo, como faz Platão, "para além da essência em dignidade", quer dizer, in-finito, sob o duplo aspecto do conteúdo e do valor. Segundo, essa transcendência significa também que o Bom mantém com toda essência uma relação de ultrapassamento: ele "requalifica" a totalidade do idêntico determinado. Sua não determinação não é indeterminação (carência, pobreza ou imprecisão), mas ultrapassamento (uperechontos) de toda determinação, pelo fato de que ele é o que atrai e orienta invencivelmente, como o faria o objeto infinito de um desejo ilimitado, a totalidade do ente ideal, o conjunto das identidades determinadas como sistema de relações 
lógico-racionais que elas estabelecem. Se o Bom platônico é de fato arche em um sentido teleológico como princípio ontológico do melhor, então ele só pode ser a razão última de toda racionalidade possível, quer dizer, a razão final universal.

Dessa perspectiva, convém devolver a Platão - contra toda leitura redutora e cética - todo o alcance de trabalho filosófico fundamental: ele se elevou até esse pensamento audacioso segundo o qual o único princípio que pode justificar racionalmente a racionalidade lógico-física mesma, quer dizer, dar razão da possibilidade da razão, é o Bom absolutamente falando, o Bem geral e absoluto, fora do qual não poderia haver princípio mais originário nem mais último.

Ora, o Bom não é, ele deve ser; não o possuímos, mas o buscamos. Ele é buscado indefinidamente por quem vive no devir; e infinitamente pelo desejo. O Bom platônico deve, portanto, ser compreendido como um telos absoluto, ou seja, como ontologicamente autônomo. Originariamente independente de toda visada intencional, ${ }^{37}$ de todo "projeto", ${ }^{38}$ de toda "vontade" ${ }^{39}$ e de toda visada subjetiva em geral, ${ }^{40}$ o Bom platônico é o fim subsistente absoluto que funda em si, incognito, as estruturas da razão. Ele assume a condição eminentemente paradoxal (do nosso ponto de vista, claro) de um ideal subsistente por si, valor-princípio que precede toda avaliação consciente, toda relação e toda identidade, posto que de todas elas é ele que dá a razão última.

É difícil não dar razão a Lévinas em sua retomada pessoal do epekeina tes ousias platônico: com efeito, não obstante a recusa por princípio praticada por Heidegger, inumeráveis índices textuais espalhados pelos diálogos platônicos, em particular na República, no Banquete, no Fedro e, ainda mais, nas passagens do Fédon evocadas aqui, confirmam que Platão estabelece o vínculo mais estreito entre seu conceito de Bom, compreendido como Bom em si (e não em um sentido simplesmente relativo como "aptidão" a uma excelência-relativamente-a) ${ }^{41}$, e os ideais éticos normativos: o Justo, o Belo, a boa ordem interna na formação do indivíduo e no governo da cidade. Todavia, permanece ainda essa diferença - e ela

\footnotetext{
${ }^{37}$ Aspecto pelo qual o platonismo de Platão opõe-se de saída a uma teoria husserliana da subjetividade.

${ }^{38}$ Por esse aspecto, o platonismo de Platão permanece irredutível e inassimilável a uma analítica do Dasein.

${ }^{39} \mathrm{O}$ que distancia também radicalmente o platonismo de Platão dos subjetivismos de um Schopenhauer ou de um Nietzsche.

${ }^{40}$ No que se cava de antemão o fosso que separa para sempre o platonismo de toda metafísica cartesiana da subjetividade.

${ }^{41}$ Como queria a interpretação heideggeriana do agathon grego, como simples Tauglichmachende, "o que torna apto", tal como já apontamos anteriormente.
} 
é crucial para distinguir entre a fundação onto-teleológica da razão no platonismo e a ética fenomenológica de Lévinas - que consiste em que o telos ideal universal de Platão não precisa de nenhum aparecer, não tem de se pronunciar nos fenômenos da palavra de um rosto. Radicalmente não fenomenológico, porque fundado sobre a distinção principial entre a ordem do ser e a ordem do aparecer, o Bom platônico precede originariamente todo conhecimento, toda subjetividade, toda doação e toda receptividade. Em suma, ele precede toda fenomenalização possível; está no começo anterior a todo começo, é princípio autossubsistente antes de toda determinidade ideal para um eventual devir; ele normatiza atraindo e justifica tornando necessária a priori a determinação mesma de toda determinidade possível do ente.

Endereço do Autor:

Université de Montpellier - Paul Valéry

Laboratoire C.R.I.S.E.S

Rue du Professeur Henri Serre - Site Saint Charles - 2ème étage

34080 - Montpellier

lavignejf@bbox.fr 